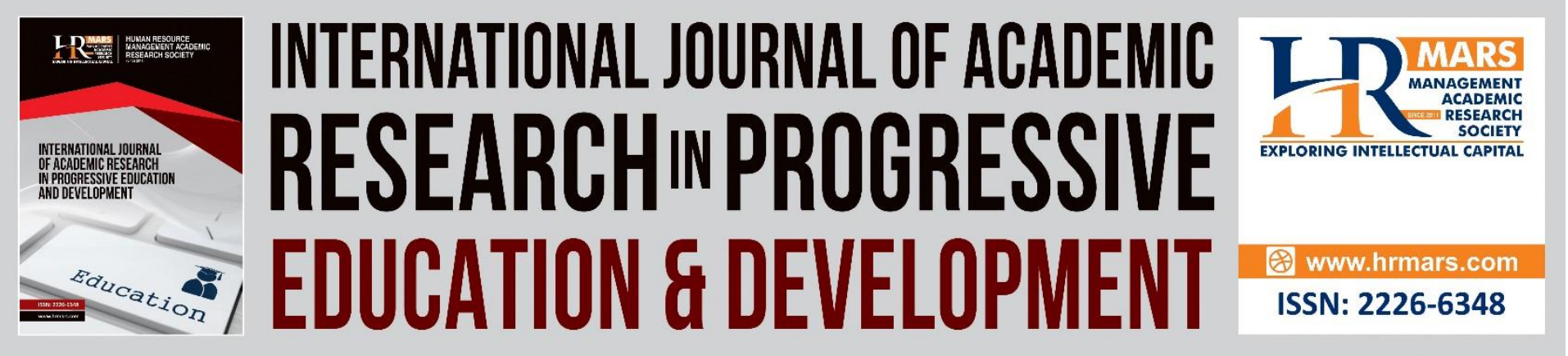

\title{
The Effect of Logical Thinking on Students Higher Order Thinking Skills
}

Tajul Rosli Shuib, Mohd Razimi Husin, Nor Hasnida Che Md Ghazali, Mohd Syaubari Othman

To Link this Article: http://dx.doi.org/10.6007/IJARPED/v10-i2/10594

DOI:10.6007/IJARPED/v10-i2/10594

Received: 10 May 2021, Revised: 14 June 2021, Accepted: 30 June 2021

Published Online: 24 July 2021

In-Text Citation: (Shuib et al., 2021)

To Cite this Article: Shuib, T. R., Husin, M. R., Ghazali, N. H. C. M., \& Othman, M. S. (2021). The Effect of Logical Thinking on Students Higher Order Thinking Skills. International Journal of Academic Research in Business and Social Sciences, 10(2), 1044-1050.

Copyright: (C) 2021 The Author(s)

Published by Human Resource Management Academic Research Society (www.hrmars.com)

This article is published under the Creative Commons Attribution (CC BY 4.0) license. Anyone may reproduce, distribute, translate and create derivative works of this article (for both commercial and non-commercial purposes), subject to full attribution to the original publication and authors. The full terms of this license may be seen at: http://creativecommons.org/licences/by/4.0/legalcode

Vol. 10(2) 2021, Pg. 1044 - 1050

http://hrmars.com/index.php/pages/detail/IJARPED

JOURNAL HOMEPAGE

Full Terms \& Conditions of access and use can be found at http://hrmars.com/index.php/pages/detail/publication-ethics 


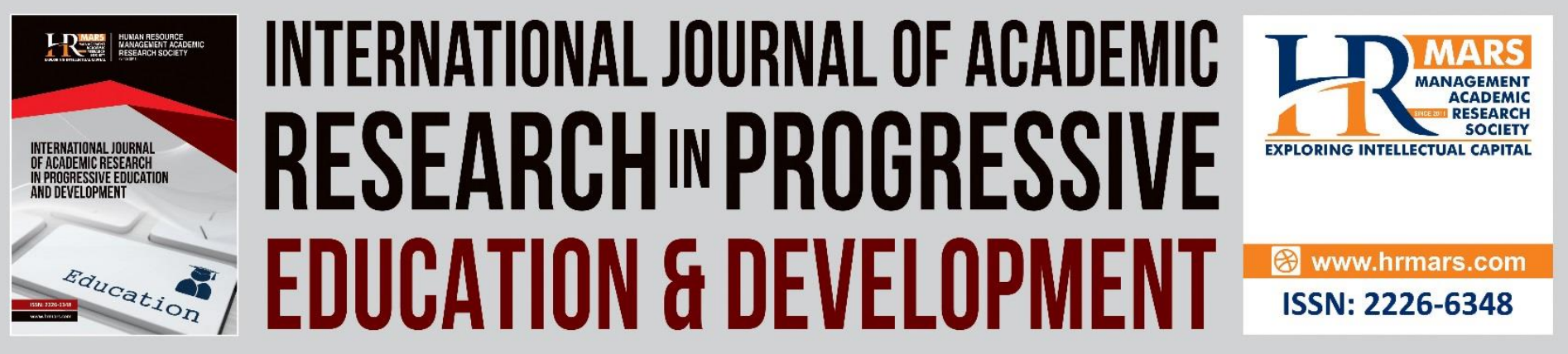

\title{
The Effect of Logical Thinking on Students Higher Order Thinking Skills
}

\author{
Tajul Rosli Shuib, Mohd Razimi Husin, Nor Hasnida Che Md \\ Ghazali, Mohd Syaubari Othman
}

Department of Educational Studies Universiti Pendidikan Sultan Idris Tanjung Malim, Perak, Malaysia

\begin{abstract}
The aim of this study is to determine the effect of logical thinking on students' Higher Order Thinking Skills (HOTS). The Infusion Learning Model of Swartz, Fischer, and Parks (1999) was used in this study. To investigate the impact of logical thinking on HOTS, a model was developed. In the first place, the interrelationship between variables was validated so that the next test could be carried out. The random cluster sampling technique was used to perform this quantitative survey study. This study had 388 participants out of a total population of 18,137 . Path analysis and Structural Equation Modelling (SEM) were used to examine the data. This study discovered that the two variables have a strong interrelationship. As a result, logical thinking variables have a significant effect on HOTS. In conclusion, the research model fits the predicted outcomes. Hopefully, further research on critical thought will be conducted in the future.
\end{abstract}

Keywords: Logical Thinking, Higher Order Thinking Skills (HOTS).

\section{Introduction}

Stated in the National Education Philosophy that students are educated to become good and citizens through the formal learning environment in school. To produce excellent citizens in the future, the education system is carefully designed so that students are more skilled and have strong cognitive abilities. This depicts the need for strong soft skills so that students can compete in either professional, partial professional or practical working markets after their graduation. Communication and problem solving are among the forms of soft skills that are highly expected from graduates who are also the backbone of every expertise available in a country. These capabilities, in turn, certainly depend on several other elements that are also important like thinking skills. It includes emotional intelligence, self-management, problem solving, creativity and so on (Rajendran, 2018). Infusion learning through the Primary/Secondary School Integrated Curriculum (KBSR/KBSM), which practices Creative and Critical Thinking Skills (KBKK) across the curriculum, has been introduced by the Ministry of Education Malaysia (MOE) to empower students' thinking abilities in the school curriculum since the early 1990s. The new Secondary School Standard Curriculum (KSSM), which places a stronger focus on High Level Thinking Skills (KBAT) and continuous student evaluation in the 
classroom, has strengthened KBSM/KBSR. As a result, the exam-oriented foundation of the school learning system is reduced (Yang \& Homg, 2018).

Curriculum and teaching experts from Malaysia and abroad were brought in to develop approaches, strategies, methods, and techniques for implementing infusion learning in the country (Rajendran, 2013). In terms of implementation, teachers face a range of challenges in adapting each approach to meet the needs of today's education, which includes influencing students' cognitive, affective, and psychomotor aspects (Audrey, 2010). Teachers and students are encouraged to engage in a variety of student-centered activities that foster teamwork, leadership, and communication skills (Mel, 2010). Even though the studentcentered approach appears to be a better way to promote critical thinking, most teachers have indicated that they are more comfortable using traditional teaching methods since they are easier to manage in terms of time and class discipline (Jasmi \& Tamuri, 2007; Rajendran, 2013). That isn't a massive issue because these traditional techniques are still crucial in the teaching of the most of the Islamic Education syllabus, particularly deep learning (Marton \& Saljo, 2005).

Teachers must consider their students' basic thought patterns in order to facilitate their ability to learn. This reasoning personality has an effect on their ability to think in different levels of thinking (Tamuri et al., 2004). The thinking ability of students are significantly influenced by their surroundings (Fisher, 2009). As a result, this is the most important thing for teachers to consider. That is why teachers play different roles with students, which is a socialization agent (Rosnani, 2012). Unlike formal classroom instruction, this necessitates more informal extra time with students, especially involving after-school activities. This simple guide is commonly referred to as Scientific Reasoning Skills in Science and Mathematics subjects, and it employs specific measurements such as the Lawson Scientific Reasoning checklist (Rajendran, 2013). If students receive a high score and a positive indicator in this assessment, they are more likely to perform well in thinking skills (Audrey, 2010).

\section{Statement of Problem}

Despite the fact that Malaysia has been using infusion learning to encourage HOTS, Rosnani (2014) discovered that students' thinking skills are still insufficient. The key reasons may be both teachers and students. Rajendran (2013) discovered, for example, that there are still a lot of teachers who don't know how to ask the right questions in the classroom. Seman (2005) and Wahap (2003) found that teachers only use low-order questions in two-way interactions, which did not work well despite the fact that it is the most significant factor in empowering good thinking skills. Learning to think critically should be supported by constructive questioning (dialogue). Furthermore, Brookfields (2015) stated that when implementing curriculum inflections and thought skills in the classroom, teachers often disregard HOTSmodeling. Teachers should be expert thinkers who can demonstrate and model how to think and talk logically and systematically. Unfortunately, Suhaimi, this does not occur in the manner in which it should (2014).

Teachers, on the other hand, can find it difficult to comprehend their students' reasoning personalities. This has an effect on the strategies they will use in training. Students would not be able to understand how to think because they have been conditioned to think in a negative and unhealthy manner. This has an impact on how they perceive the world and how they make decisions now and in the future (Ellen, 2014). It's called Reasoning Personality in this research, and the simple everyday reasoning comes from their surroundings. For example, if 
they are conditioned to think negatively about others, they will still make negative assumptions about that person, although there is another factor to consider. Aside from formal interactions in the classroom, students must be known individually and socially. Since there is little research regarding reasoning personalities (Scientific Reasoning Skills) in Social Science, it should be expanded to help teachers better understand their students' situations and decide the best ways to socialize with them both within and outside of class. Teachers have the ability to change students' social personalities in order to change their thinking personalities. Thus the effect of logical thinking as a basic thinking style for students on HOTS needs to be studied.

\section{Research Objectives}

The main objective of this study is to identify the effect of Logical Thinking on Higher Order Thinking Skills.

\section{Study Hypotheses}

$$
\begin{aligned}
& \mathrm{H}_{\mathrm{a}}{ }^{01} \text { Logical Thinking has a significant effect on the formation of students' } \\
& \text { Higher Order Thinking Skills. }
\end{aligned}
$$

\section{Research Methodology}

This is a quantitative survey study. A questionnaire was used to collect data. Validity and reliability have been established for all constructs. The Logical Thinking construct is based on a list by Neil and Stuart (2007), while Rosnani (2014) and Rajendran's research instruments for higher order thought skills were adapted (2008). Purposive and random sampling techniques were used to choose 388 respondents from a population of 18,137 . Data was analyzed using path analysis and Structural Equation Modeling to validate the hypotheses (SEM).

\section{Findings}

Hypothesis Test for 'Causal Effect' of Students ' Logical Thinking Has a Significant Impact on the Formation of Students' Higher Order Thinking Skills

\begin{tabular}{lllllll}
\hline & & Beta Value & S.E. & C.R. & P & Result \\
\hline HOTS $<--$ & $\begin{array}{l}\text { Logical } \\
\text { Thinking }\end{array}$ & 0.754 & 0.091 & 8.258 & $* * *$ & Significant \\
& & & & & & \\
\end{tabular}

Definition for the significance level for regression weight: Based on the table above, the $p$ value $(p=* * *)$ from the analysis shows less than the significance level of 0.05 , so this null hypothesis is rejected. This means, alternative hypotheses are supported. So, in conclusion the Thinking Personality of students has a significant effect on the Higher Order Thinking Skills of students.

\section{Discussion}

The role of Logical Thinking in improving students' thinking skills has been evidenced in this research. Students are expected to think clearly and rationally in both their personal lives and academic studies. This may be a motivation for teachers to place a greater focus in the classroom on the affective side (rohani) rather than the cognitive and psychomotor aspects. 
Furthermore, this scenario demonstrates that students can learn contextually. To achieve the learning goals of the 21st century, teachers must vary the atmosphere of the learning environment. It should be carried out regularly because personality is malleable, particularly when it comes to youth. Aside from that, this study demonstrated that good teachers make an effort to build a positive relationship with their students. It's because logical thinking is all about people's social and emotional connections. This relationship is crucial in shaping students' spiritual identities in Islamic education.

The findings of this study supported the findings of Primi, Morsanyi, and Chiesi (2014), as well as Gerber, Cavallo, and Marek (2001), who found that scientific thinking abilities (reasoning personality) is an important element to support HOTS. Despite the fact that those studies were conducted from the viewpoints of Science and Mathematics, the same scenario was depicted to clarify the close interrelationship between the variables discussed. Abu Hassan, Saad and Dollah (2012) clarified the importance of Logical Thinking with extensive research to prove the impact on students' thinking abilities when infusion learning is practised continuously and in a formal order. These studies also indicate that the reasoning personality is a topic of discussion around the world in order to ensure that our children grow up in a safe mental-reasoning atmosphere.

To deal with the Logical Thinking issue, the state education department and teachers should work together. Teachers are encouraged to create detailed modules that incorporate factors such as reasoning character in their evaluations. This is to ensure that all teachers have a consistent emphasis and approach to students in order to bring them closer to Islamic thought. This will aid them in better understanding Islam and developing into strong Muslims as Malaysia's future leaders. Aside from that, students will be able to study Islamic Education enthusiastically and sincerely without feeling compelled to do so, as learning is only successful when students learn it willingly and sincerely.

\section{Conclusion}

This study's outcome met the research's expectations. The importance of logical thought in the growth of students' thinking skills cannot be overstated. More research on reasoning personality should be conducted, especially in the context of Islamic education, where it is still lacking. Hopefully, this study will give teachers and education administrators in Malaysia some ideas about how to pay more attention to students' reasoning wellbeing. Teachers who understand their students emotionally as well as academically would be successful socialisation agents

\section{References}

Abu Hassan, M. E., Saad, N. S., \& Dollah, M. U. (2012). Kemahiran Penaakulan Saintifik (KPS) dalam kalangan pelajar Tingkatan Empat dan hubungannya dengan stail pengajaran guru Matematik di Bilik Darjah. Jurnal Pendidikan Sains \& Matematik Malaysia, 2(2), 1-10.

Anderson, L. W., \& Krathwohl, D. R. (2001). A taxonomy for learning, teaching, and assessing: A revision of Bloom's taxonomy of educational objectives. Longman.

Braun, J. D., Strunk, D. R., Sasso, K. E., \& Cooper, A. A. (2015). Therapist use of Socratic questioning predicts session-to-session symptom change in cognitive therapy for depression. Behaviour research and therapy, 70, 32-37. 
Brookfields, S. (2005). The power of critical theory for adult learning and teaching. The Adult Learner, 85.

Coombs, B. (2009). Mengajar Secara Efektif. (Terjemahan: Siti Aishah Mohd Elias). Kuala Lumpur: Institut Terjemahan Negara Malaysia.

De Bono, E. (2000). Six Thinking Hats. London: Penguin Books.

De Bono, E. (2015). Serious Creativity: How to be creative under pressure and turn ideas into action. New: York: Random House.

Lambert, E. R. (2014). The Power of Creative Thinking. Kuala Lumpur: YLP Publication.

Fisher, R. (2007). Dialogic teaching: Developing thinking and metacognition through philosophical discussion. Early Child Development and Care, 177(6-7), 615-631.

Fisher, R. (2013). Creative dialogue: Talk for thinking in the classroom. Routledge.

Hashim, R. (2003). Malaysian Teachers' Attitudes, Competency and Practices in the Teaching of Thinking. Intellectual Discourse, 11(1).

Hashim, R. (2012). Memenuhi Aspirasi Kemahiran Berfikir dalam Pelan Pembangunan Pendidikan Malaysia 2013-2025 menerusi inkuiri dan pedagogi filosofiyyah dalam kalangan guru. Persidangan Majlis Dekan Fakulti Pendidikan, Universiti Teknologi Malaysia.

Hussin, H. (2012). Worldview Dan Amalan: Pengalaman Kadazan Dataran Penampang Sabah. Borneo Research Journal, University of Malaya, 1(1).

Jasmi, K. A., \& Tamuri, A. H. (2007). Pendidikan Islam: kaedah pengajaran \& pembelajaran. Penerbit UTM Press.

Jeffrey, B., \& Woods, P. (2009). Creative learning in the primary school. Routledge.

Kanazawa, T., Satoshi \& Norman, Li. (2015). Happiness in modern society: Why intelligence and ethnic composition matter. Journal of Research in Personality, 59(4), 111-120.

Marton, F., \& Saljo, R. (2005). Approaches to learning In F. Marton, D. Hounsell \& NJ Entwistle. The experience of learning: implications for teaching and studying in higher education. 3rd (Internet) edition.

Mayer, R. E., Stull, A., DeLeeuw, K., Almeroth, K., Bimber, B., Chun, D., \& Zhang, H. (2009). Clickers in college classrooms: Fostering learning with questioning methods in large lecture classes. Contemporary Educational Psychology, 34(1), 51-57.

Mohd, A., \& Hassan, A. (2014). Pemikiran reka cipta. PTS Media Group Sdn Bhd.

Osler, A. (2010). Students' perspectives on schooling. McGraw-Hill Education (UK).

Rajendran, N. (2013). Teaching and Acquiring Higher Order Thinking Skills: Theory and Practice. Tanjung Malim: Penerbit Universiti Pendidikan Sultan Idris.

Rashid, A. R. A. (2001). Nilai-Nilai Murni Dalam Pendidikan: Menghadapi Perubahan dan Cabaran Alaf Baru. Kuala Lumpur: Utusan Publications and Distributions.

Paul, R., \& Elder, L. (2019). The miniature guide to critical thinking concepts and tools. Rowman \& Littlefield.

Robert, F. (2009). Creative Dialogue: Talk for Thinking in the Classroom. New York: Routledge.

Arbaa, R., Jamil, H., \& Abd Razak, N. (2010). Hubungan guru-pelajar dan kaitannya dengan komitmen belajar pelajar: Adakah guru berkualiti menghasilkan perbezaan pembelajaran antara jantina pelajar. Jurnal Pendidikan Malaysia, 35(2), 61-69.

Rosnaini, S., Maimun, A., \& Mok, S. S. (2011). Siri Kemahiran Generik: Kemahiran Berfikir. Selangor: Penerbitan Multimedia Sdn Bhd.

Seman, S. (2005). Interaksi lisan dalam pengajaran dan pembelajaran komponen Kesusasteraan Melayu (Komsas) dalam mata pelajaran Bahasa Melayu.Tesis Doktor Falsafah. Fakulti Pendidikan, Universiti Kebangsaan Malaysia, Bangi. 
Silberman, M. (2010). Pembelajaran Aktif: 101 Strategi Untuk Mengajar Apa Jua Subjek. (Terjemahan: Zainab Ahmad). Kuala Lumpur: Institut Terjemahan Negara Malaysia.

Rajendran, N. (2018). Pengajaran dan Penguasaan Kemahiran Berfikir Aras Tinggi: Teori dan Amalan. Tanjung Malim: Penerbit Universiti Pendidikan Sultan Idris.

Stephen, R. C. (2013). The Seven Habits of Highly Effective People. United Kingdom: Simon \& Schuster UK Limited.

Swartz, R. J., Fischer, S. D., \& Parks, S. (1998). Infusing the Teaching of Critical and Creative Thinking into Secondary Science: A Lesson Design Handbook. Critical Thinking Books and Software, PO Box 448, Pacific Grove, CA 93950-0448.

Taat, M. S. (2011). Gaya Pertautan dan Motivasi Pelajar, Serta Pengajaran dan Bimbingan Guru Pendidikan Islam Terhadap Pembelajaran Terarah Kendiri (PTK) Pelajar. Tesis PhD. Universiti Malaysia Sabah.

Tamuri, A. H., Yusop, A., Osman, K., Awaluddin, S., Rahim, Z. A., \& Razak, K. A. (2004). Keberkesanan P\&P Pendidikan Islam ke Atas Pembangunan Diri Pelajar. Laporan Penyelidikan Fakulti Pendidikan, UKM dan Jabatan Pendidikan Islam dan Moral (JAPIM), KPM.

Tamuri, A. H., Mahmud, Z., \& Bari, S. (2005). Permasalahan pelajar-pelajar fakir miskin di daerah Sabak Bernam. Jurnal Pendidikan, 30, 21-33.

Tegin, J., Ekvall, S., Kragic, D., Wikander, J., \& Iliev, B. (2009). Demonstration-based learning and control for automatic grasping. Intelligent Service Robotics, 2(1), 23-30.

Yang, Z., \& Homg, M. (2018). Latest Policies of Basic Education Reform in Malaysia: Background, Contents and Features of "Malaysia Education Blueprint 2013-2025 (Preschool to Post-Secondary Education)". International and Comparative Education, 1(5).

Wahap, W. (2003). Penggunaan penyoalan lisan dalam kalangan guru Sejarah di sekitar bandar Sibu. Kertas Projek Sarjana Pendidikan. Fakulti Pendidikan, Universiti Kebangsaan Malaysia, Bangi. 